Volume 3, Number 2, Agustus 2020

p-ISSN: 2615-0212 | e-ISSN: 2621-2838

https://ejournal.iaifa.ac.id/index.php/dirasah

\begin{tabular}{|c|c|c|}
\hline Accepted: & Revised: & Published: \\
Juni 2020 & Juli 2020 & Agustus 2020 \\
\hline
\end{tabular}

\title{
Peran Penyuluh Agama Islam Fungsional dalam Melakukan Pembinaan terhadap Narapidana di Rumah Tahanan Kelas II-B Kabupaten Bangkalan(Perspektif Komunikasi Sosial dan Agama)
}

\author{
Muchlis \\ UIN Sunan Ampel Surabaya, Indonesia \\ Email:muchlis79@uinsby.ac.id
}

\begin{abstract}
The research used a qualitative approach and was designed based on the framework of phenomenological study. The research found out that: 1) The role of functional Islamic counselor in an effort to provide guidance to prisoners in Bangkalan's jail of class II-B by using the approach of social and religious communication manifested in the form of routine counseling in every Friday for twice a month, precisely in the first week and the third week. The forms of counseling activities conducted by the functional Islamic counselor among prisoners are: reciting al-Qur'an (i.e. Yasin), tahlil, istighosah, and prayer; delivering religious lectures; and using a guidance and counseling approach in an effort to resolve the problems experienced by prisoners. 2) Constraints faced by functional Islamic religious counselor in providing guidance to prisoners in Bangkalan's jail of class II-B by using social and religious communication approach are the existence of both internal and external constraints. The forms of internal constraints are:the differences in the cultural background of the prisoners, the differences in the educational background of the prisoners, and the differences in the cases behind the prisoners who had to undergo sentences in the jail.Meanwhile, the form of external constraints is inadequate infra structure of bathrooms in the jail of class II-B in Bangkalan Regency.
\end{abstract}

Keywords: Functional Islamic counselor, prisoners, religious communication. 


\begin{abstract}
Abstaksi
Penelitian ini menggunakan pendekatan kualitatif-eksploratif dan didesain dalam bingkai studi fenomenologi. Hasil penelitian ini menunjukkan bahwa: 1) Peran penyuluh agama Islam fungsional dalam upaya melakukan pembinaan terhadap narapidana di rutan kelas II-B Kabupaten Bangkalan dengan menggunakan pendekatan komunikasi sosial dan agama termanifestasikan dalam bentuk melakukan penyuluhan secara rutin di rutan kelas II-B Kabupaten Bangkalan, yaitu setiap hari Jum'at selama dua kali dalam satu bulan, tepatnya pada minggu pertama dan minggu ketiga. Kegiatan pembinaan yang berbentuk pemberian penyuluhan yang dilakukan oleh penyuluh agama Islam fungsional tersebut, antara lain:mengajak para narapidana untuk membaca surat Yasin, tahlil, istighasah, dan shalawat; memberikan ceramah agama; serta menggunakan pendekatan bimbingan dan konseling dalam upaya menyelesaikan permasalahan yang dialami oleh para narapidana.2) Kendalakendala yang dihadapi oleh penyuluh agama Islam fungsional dalam upaya melakukan pembinaan terhadap narapidana di rutan kelas II-B Kabupaten Bangkalan dengan menggunakan pendekatan komunikasi sosial dan agama yaitu adanya kendala internal dan eksternal. Kendala internal berupa: adanya perbedaan latar belakang budaya dari para narapidana, adanya perbedaan latar belakang pendidikan dari para narapidana, dan adanya perbedaan kasus yang melatar belakangi para narapidana sehingga mereka harus menjalani masa hukuman di rutan. Sedangkan kendala eksternal berupa kurang memadainya infra struktur kamar mandi yang ada di rutan kelas II-B Kabupaten Bangkalan.
\end{abstract}

Kata kunci: Penyuluh Agama Islam Fungsional, Narapidana,Komunikasi Agama

\title{
Pendahuluan
}

Penyuluh agama fungsional merupakan Pegawai Negeri Sipil (PNS) yang diberi tugas, tanggung jawab, wewenang dan hak secara penuh oleh pejabat yang berwenang untuk melaksanakan bimbingan atau penyuluhan agama dan pembangunan kepada masyarakat melalui pendekatan bahasa agama ${ }^{1}$. Dengan kata lain, kedudukan penyuluh agama berada pada instansi pemerintah sebagai pelaksana teknis fungsional bimbingan keagamaan atau penyuluhan dan pembangunan melalui bahasa agama kepada masyarakat. ${ }^{2}$

\footnotetext{
${ }^{1}$ Badan Litbang dan Diklat Kemenag RI, "Naskah Akademik Bagi Penyuluh Agama” (Jakarta, 2015).

${ }^{2}$ Ditjen Bimas Islam Kemenag RI, Himpunan Peraturan Tentang Jabatan Fungsional Penyuluh Agama Dan Angka Kreditnya (Jakarta: Ditjen Bimas Islam Kemenag RI, 2011).
}

Dirasah, Vol. 3, No.2, Agustus 2020 
Berdasarkan pengertian tentang penyuluh agama fungsional diatas, terlihat dengan jelas bahwa dalam menjalankan tugasnya, para penyuluh agama fungsional berhadapan langsung dengan kondisi riil yang dialami dan dirasakan oleh masyarakat. Saat ini, penyuluh agama fungsional berhadapan dengan suatu kondisi masyarakat yang berubah dengan cepat yang mengarah pada masyarakat fungsional, masyarakat teknologi, masyarakat saintifik, dan masyarakat terbuka. Dengan demikian, setiap penyuluh agama fungsional terus menerus perlu meningkatkan pengetahuan, wawasan dan pengembangan diri, dan juga perlu memahami visi penyuluh agama serta menguasai secara optimal terhadap materi penyuluhan agama itu sendiri maupun teknik penyampaiannya. Sehingga ada korelasi faktual terhadap kebutuhan masyarakat pada setiap gerak dan langkah mereka. ${ }^{3}$ Tanpa membekali diri dengan berbagai keahlian sebagaimana tersebut diatas, perjuangan para penyuluh agama fungsional dalam upaya memberikan bimbingan atau penyuluhan kepada masyarakat dengan menggunakan bahasa agama, akan terasa sangat berat.

Melihat begitu mulianya tugas para penyuluh agama fungsional dalam memainkan perannya di masyarakat, sehingga tidak terlalu berlebihan jika Menteri Agama Republik Indonesia (Lukman Hakim Saifuddin) pernah berujar bahwa penyuluh agama adalah juru penerang, pelita ditengah kegelapan, yang memberikan pencerahan dan mengajarkan kearifan bagi masyarakat sekitarnya. ${ }^{4}$ Hal ini menegaskan bahwa peran penyuluh agama fungsional dalam kehidupan masyarakat tidak bisa dipandang sebelah mata. Sebaliknya, keberadaannya harus terus didukung demi terwujudnya kehidupan masyarakat yang harmonis, tenteram, dan penuh dengan kedamaian. Tanpa adanya dukungan dari berbagai pihak, langkah penyuluh agama fungsional akan terasa berat dalam menjalankan tugasnya.

Dalam menjalankan tugasnya, sasaran masyarakat yang dijadikan objek pemberian bimbingan atau penyuluhan oleh para penyuluh agama fungsional meliputi beraneka ragam struktur sosial. Dari sisi sosiologis, meliputi: masyarakat pedesaan, masyarakat terasing, masyarakat kota besar dan kecil, dan masyarakat marginal. Dari segi struktur kelembagaan, berupa: masyarakat

\footnotetext{
${ }^{3}$ Mukhlisuddin, "Peran Penyuluh Agama Islam Dalam Mereduksi Konflik Dan Mengintegrasikan Masyarakat (Studi Kasus Konflik Pelaksanaan Shalat Tarawih Di Kecamatan Bandar Dua, Kabupaten Pidie Jaya)," Jurnal Bimas Islam 9, no. 1 (2016).

"Majalah Bimas Islam Kementerian Agama RI Edisi 4," Ditjen Bimas Islam Kemenag RI, 2016.
} 
secara umum, pemerintah, dan keluarga. Dari segi sosio-kultural, meliputi: priyayi, santri, dan abangan. Dari segi usia, meliputi: anak-anak, remaja, dan orang tua. Dari segi profesi, terdiri dari: petani, pedagang, seniman, buruh, dan pegawai negeri. Dari segi sosial-ekonomi, meliputi: kaya, menengah, dan miskin. Dan dari segi jenis kelamin, terdiri dari: laki-laki dan perempuan. ${ }^{5}$

Terkait dengan sasaran masyarakat yang dijadikan sebagai objek pemberian bimbingan atau penyuluhan oleh para penyuluh agama fungsional tersebut diatas, para narapidana yang berada di rumah tahanan (rutan) kelas II-B Kabupaten Bangkalan juga termasuk dalam kategori segmen masyarakat yang keberadaannya sangat diperhatikan oleh para penyuluh agama Islam fungsional yang berada dalam naungan Kantor Kementerian Agama Kabupaten Bangkalan. Oleh karena itu, secara rutin para penyuluh agama fungsional memberikan bimbingan atau penyuluhan dalam rangka melakukan pembinaan terhadap para narapidana di rutan kelas II-B yang terletak di Jl. Pertempuran No. 21 Pejagan, Kecamatan Bangkalan, Kabupaten Bangkalan. Dimana para narapidana yang ada di rutan kelas II-B Kabupaten Bangkalan tersebut memiliki berbagai macam permasalahan hidup yang pernah dialaminya, sehingga mereka ditetapkan bersalah secara hukum dan harus menjadi penghuni rutan. Permasalahan yang pernah dialami oleh para narapidana kelas II-B Kabupaten Bangkalan diantaranya: kasus narkoba (baik sebagai pemakai maupun penjual), pencurian, penggelapan, pemerkosaan, pengeroyokan, pembunuhan, korupsi, dan berbagai permasalahan kriminal lainnya.

Berdasarkan realitas diatas, penelitian ini sengaja dilakukan untuk mengungkap secara mendalam mengenai peran penyuluh agama Islam fungsional dalam upaya melakukan pembinaan terhadap narapidana di rutan kelas II-B yang terletak di Jl. Pertempuran No. 21 Pejagan, Kabupaten Bangkalan dengan mengkajinya dalam perspektif komunikasi sosial dan agama. Dan perlu diketahui bahwa istilah penyuluh agama Islam fungsional sengaja digunakan dalam penelitian ini dengan pertimbangan untuk memberikan batasan yang jelas antara penyuluh agama Islam fungsional dan penyuluh agama Islam honorer (non PNS). Disamping itu, dalam praktiknya di lapangan, juga terdapat penyuluh agama fungsional lainnya (penyuluh agama Kristen fungsional, penyuluh agama Hindu fungsional, dan penyuluh agama Budha fungsional).

\footnotetext{
${ }^{5}$ Badan Litbang dan Diklat Kemenag RI, "Naskah Akademik Bagi Penyuluh Agama."
}

Dirasah, Vol. 3, No.2, Agustus 2020 
Penelitian ini penting untuk dilakukan mengingat penelitian-penelitian yang ada selama ini belum pernah ada yang menyentuh aspek kontribusi penyuluh agama Islam fungsional dalam upaya melakukan pembinaan terhadap para narapidana, apalagi mengkajinya dengan menggunakan pendekatan komunikasi sosial dan agama. Penelitian yang pernah dilakukan oleh Abdul Basit misalnya.Ia hanya memfokuskan penelitiannya pada kajian seputar tantangan-tantangan yang dihadapi oleh penyuluh agama Islam di Indonesia dan langkah-langkah apa saja yang harus dipersiapkan oleh institusi pendidikan dakwah, organisasi dakwah, dan pemerintah dalam menghadapi tantangantantangan tersebut. Selain itu, ada pula penelitian yang pernah dilakukan oleh Fatatun Mufidah. Dalam penelitiannya, ia hanya fokus mengkaji mengenai bagaimana upaya penyuluh agama Islam Kementerian Agama Kabupaten Jember dan Bondowoso dalam mengembangkan dakwah dan bagaimana program kerja, sosialisasi serta pemberdayaan internal dan eksternalnya. Disamping itu, ada pula penelitian yang mengkaji tentang sepak terjang penyuluh agama Islam yang dilakukan oleh Cikdin. Permasalahan utama yang dikaji dalam penelitiannya adalah tentang bagaimana peran penyuluh agama honorer dalam upaya melakukan perubahan perilaku ibadah anak di Desa Batu Dewa dan faktor-faktor apa saja yang mempengaruhi perubahan perilaku ibadah anak di Desa Batu Dewa.

Berdasarkan telaah terhadap beberapa hasil penelitian tersebut diatas, menggambarkan bahwa penelitian-penelitian tersebut tidak ada yang secara spesifik mengkaji mengenai peran penyuluh agama Islam fungsional dalam upaya melakukan pembinaan terhadap para narapidana. Penelitian-penelitian tersebut lebih terfokus pada kajian mengenai peran penyuluh agama Islam, bahkan ada yang secara spesifik mengkaji mengenai peran penyuluh agama Islam honorer, dalam upaya melakukan pemberdayaan masyarakat di luar rutan. Oleh karena itu, kehadiran penelitian ini berorientasi untuk mengkaji mengenai peran penyuluh agama Islam fungsional dalam upaya melakukan pembinaan terhadap narapidana di rutan kelas II-B Kabupaten Bangkalan. Dengan pertimbangan bahwa kehadiran penelitian ini sangat bermanfaat untuk menambah deretan penelitian mengenai peran penyuluh agama Islam fungsional dalam upaya melakukan pembinaan terhadap masyarakat (khususnya masyarakat yang berstatus sebagai narapidana) ditinjau dari aspek keilmuan komunikasi, khususnya dalam perspektif komunikasi sosial dan agama. 
Permasalahan utama yang dikaji dalam penelitian ini adalah: 1) Bagaimanakah peran penyuluh agama Islam fungsional dalam upaya melakukan pembinaan terhadap para narapidana yang ada di rutan kelas II-B Kabupaten Bangkalan dengan menggunakan pendekatan komunikasi sosial dan agama ?. 2) Kendala-kendala apa saja yang dihadapi oleh penyuluh agama Islam fungsional dalam upaya melakukan pembinaan terhadap para narapidana yang ada di rutan kelas II-B Kabupaten Bangkalan dengan menggunakan pendekatan komunikasi sosial dan agama?.

\section{Metode Penelitian}

Penelitian ini menggunakan pendekatan kualitatif karena dimensi riset yang berbicara tentang peran penyuluh agama Islam fungsional dalam upaya melakukan pembinaan terhadap narapidana di rutan kelas II-B Kabupaten Bangkalan dengan menggunakan pendekatan komunikasi sosial dan agama mutlak memerlukan uraian kata-kata dan analisa-analisa yang berbentuk kalimat naratif. Pendekatan kualitatif dipilih mengingat riset ini didasarkan atas proses usaha membangun gambaran fakta secara holistik-komprehensif dan membentuk kata-kata akurat yang deskriptif-eksploratif dari para informan terkait dengan permasalahan yang dikaji dalam penelitian ini. ${ }^{6}$

Dengan menggunakan pendekatan kualitatif, riset ini memaksimalkan upaya untuk menemukan makna-makna yang ada dalam benak komunikator (penyuluh agama Islam fungsional) pada saat mereka berbicara dengan orang lain (para narapidana yang ada di rutan kelas II-B Kabupaten Bangkalan) ketika terjadi proses penyuluhan untuk mengkaji tindakan-tindakan dan makna-makna komunikatif tersebut. ${ }^{7}$ Fenomena yang diambil adalah proses komunikasi sosial dan agama yang dilakukan oleh penyuluh agama Islam fungsional yang nota bene merupakan Pegawai Negeri Sipil (PNS) yang berada dibawah naungan Kantor Kementerian Agama Kabupaten Bangkalan dalam upaya melakukan pembinaan terhadap narapidana di rutan kelas II-B Kabupaten Bangkalan. Model fenomenologi diambil dalam riset ini karena bertujuan untuk melihat

\footnotetext{
${ }^{6}$ Christine Daymon and Immy Holloway, Metode-Metode Riset Kualitatif Dalam Public Relations \& Marketing Communications, ed. Terj. Cahya Wiratama (Yogyakarta: Bentang, 2008).

${ }^{7}$ Andi Bulaeng, Metode Penelitian Komunikasi Kontemporer (Yogyakarta: Andi Offset, 2004).
}

Dirasah, Vol. 3, No.2, Agustus 2020 
objek secara holistik dan natural, bukan secara parsial. ${ }^{8}$ Sehingga fenomena komunikasi sosial dan agama yang dilakukan oleh penyuluh agama Islam fungsional dalam upaya melakukan pembinaan terhadap narapidana di rutan kelas II-B Kabupaten Bangkalan nampak jelas terlihat. Hal ini berarti mengeksplorasi suatu masalah secara terperinci, melakukan pengambilan data secara mendalam, dan menyertakan berbagai sumber informasi sangat diperlukan.

Penelitian ini menggunakan tiga teknik pengumpulan data, yaitu wawancara semi terstruktur, observasi dan dokumentasi. Terkait dengan teknik wawancara, riset ini menetapkan informan utama (key informan) yang akan diwawancarai dalam penelitian. Informan ini akan diambil dari dua sasaran, yaitu dari pihak penyuluh agama Islam fungsional Kantor Kementerian Agama Kabupaten Bangkalan, dan para narapidana yang ada di rutan kelas II-B Kabupaten Bangkalan.

Data-data penelitian yang sudah terkumpul kemudian dianalisa dengan menggunakan teknikanalisis domain (domain analysis). Teknik analisis ini digunakan untuk menganalisis gambaran objek penelitian secara umum atau di tingkat permukaan, namun relatif utuh dalam menggambarkan tentang objek penelitian. Teknik analisis ini juga sengaja digunakan karena penelitian ini bersifat eksplorasi. Artinya, analisis hasil penelitian ini hanya ditargetkan untuk memperoleh gambaran yang seutuhnya dari objek yang diteliti, tanpa harus diperincikan secara detail unsur-unsur yang ada dalam keutuhan objek penelitian. ${ }^{9}$

\section{Konsepsi Komunikasi Sosial}

Komunikasi sosial merupakan sebuah bentuk komunikasi yang sangat penting dilakukan untuk membangun konsep diri, untuk kelangsungan hidup, aktualisasi diri, untuk memperoleh kebahagiaan, terhindar dari tekanan dan ketergantungan, serta untuk memupuk hubungan dengan orang lain. Melalui komunikasi sosial, seseorang bisa bekerja sama dengan anggota masyarakat

\footnotetext{
${ }^{8}$ Ida Bagoes Mantra, Filsafat Penelitian Dan Metode Penelitian Sosial (Yogyakarta: pustaka Pelajar, 2004).

${ }^{9}$ Burhan Bungin, Analisis Data Penelitian Kualitatif(Jakarta: Raja Grafindo Persada, 2004).
} 
(keluarga, kelompok belajar, perguruan tinggi, RT, RW, desa, kota, dan negara secara keseluruhan) untuk mencapai tujuan bersama. ${ }^{10}$

Bentuk komunikasi sosial secara substansial meliputi: komunikasi interpersonal (komunikasi antar pribadi), komunikasi kelompok, dan komunikasi massa. Menurut Pace yang dikutip oleh Cangara, komunikasi interpersonal adalah proses komunikasi yang berlangsung antara dua orang atau lebih dengan tatap muka. Komunikator relatif cukup mengenal komunikan dan pesan yang dikirim maupun diterima dapat menghasilkan umpan balik secara spontan. $^{11}$

Komunikasi interpersonal mempunyai peranan dalam membentuk hubungan perasaan, pemahaman informasi, dukungan, citra diri, dan pemahaman atas harapan orang lain. Di sisi lain, proses komunikasi interpersonal dapat menentukan berkembangnya dan berakhirnya hubungan. Untuk mengembangkan hubungan, terdapat empat poin penting dalam proses komunikasi interpersonal. Pertama, pengungkapan diri (self disclosure). Pengungkapan diri adalah proses pengungkapan informasi diri seseorang kepada orang lain atau sebaliknya. Proses pengungkapan diri dilakukan secara tertutup melalui ungkapan dan tindakan yang akan terbuka dengan sendirinya tentang sesuatu pada diri seseorang. Kedua, penetrasi sosial. Penetrasi sosial adalah proses yang dialami seseorang untuk saling mengenal dengan orang lain, sehingga secara bertahap akan mempermudah dalam membahas topik pembicaraan yang lebih pribadi.Ketiga, proses pandangan (process of view). Teori ini menganggap bahwa kualitas dan sifat hubungan dapat diperkirakan hanya dengan menggunakan dan mengkombinasikan atribut masing-masing sebagai individu, seperti senyuman. Namun, senyuman memiliki makna yang berbeda jika dilakukan oleh orang dan obyek, serta situasi yang berbeda pula. Hubungan intensif antara orang-orang dalam kelompok primer dapat menyebabkan lahirnya proses pandangan. Keempat, pertukaran sosial (social exchange). Pertukaran sosial menelaah tentang kontribusi seseorang dalam suatu hubungan untuk mempengaruhi orang lain. Menurut Thibaut dan Kelley dalam Sendjaja yang dikutip oleh Bungin, seseorang mengevaluasi hubungannya dengan orang lain dan mempertimbangkan konsekuensinya, khususnya terhadap upaya dan ganjaran. Asumsi tentang perhitungan antara

\footnotetext{
${ }^{10}$ Jalaluddin Rakhmat, Psikologi Komunikasi (Bandung: Remaja Rosda Karya, 2007).

${ }^{11}$ Hafied Cangara, Pengantar Ilmu Komunikasi (Jakarta: Raja Grafindo Persada, 1998).
}

Dirasah, Vol. 3, No.2, Agustus 2020 
upaya dan ganjaran bukan berarti seseorang senantiasa untuk saling mengeksploitasi, tetapi lebih memilih lingkungan dan hubungan yang diinginkannya. $^{12}$

Sementara itu, komunikasi interpersonal tidak terlepas dari pengaruh kelompok, tetapi konsep komunikasi hanya melihat konten dari komunikasi yang dibangun oleh individu masing-masing. Hal itu berbeda dengan konsep komunikasi kelompok, yaitu konten komunikasi dipengaruhi oleh motivasi bersama, tujuan-tujuan yang ingin dicapai, persepsi bersama, kesan-kesan yang tumbuh, model kepemimpinan yang dibangun, dan pengaruh-pengaruh eksternal yang dialami oleh kelompok akan saling mempengaruhi anggota kelompok. Kelompok adalah sekumpulan orang-orang yang terdiri dari dua atau tiga bahkan lebih. Kelompok yang dimaksud menjadi deskripsi dari kelompok kecil, tetapi tidak ada batasan yang jelas terkait jumlah orang yang berada dalam satu kelompok kecil. ${ }^{13}$ Pada umumnya, komunikasi kelompok melibatkan komunikasi interpersonal, sehingga umpan balik dapat diterima dengan segera dan menentukan penyampaian pesan berikutnya.

Kelompok juga memberi identitas terhadap individu yang secara tidak langsung dapat membantu berhubungan dengan satu sama lain. Adanya identitas membuat individu melakukan pertukaran fungsi dengan individu lain dalam kelompok. Karakteristik komunikasi dalam kelompok terdiri dari norma dan peran. Selain itu, eksistensi suatu kelompok dalam masyarakat dapat dicerminkan oleh adanya fungsi-fungsi yang akan dilaksanakan. Menurut Sendjaja yang dikutip oleh Bungin, fungsi-fungsi tersebut mencakup hubungan sosial, pedagogis, persuasi, pemecahan masalah dan pembuatan keputusan, serta terapi. Fungsi pertama dalam kelompok adalah hubungan sosial yang berarti suatu kelompok dapat memelihara dan memantapkan hubungan sosial dengan para anggotanya, seperti memberikan kesempatan dalam melakukan kegiatan rutin yang informal, santai, dan menghibur. Fungsi kedua dalam kelompok adalah pedagogis yang berarti suatu kelompok secara formal maupun informal bekerja untuk mencapai pengetahuan.Fungsi ketiga dalam kelompok adalah persuasi yang berarti seorang anggota kelompok berupaya mempersuasi anggota lainnya agar melakukan sesuatu yang berlandaskan nilai-nilai positif.

\footnotetext{
${ }^{12}$ Burhan Bungin, Sosiologi Komunikasi: Teori, Paradigma, Dan Diskursus Teknologi Komunikasi Di Masyarakat (Jakarta: Kencana, 2007).

${ }^{13}$ Ibid.
} 
Fungsi keempat dalam kelompok adalah pemecahan masalah dan pembuatan keputusan yang berarti cerminan dari kelompok untuk membuat kegiatankegiatan sebagai penemuan alternatif atau solusi. Fungsi kelima dalam kelompok adalah terapi yang berarti suatu kelompok membantu setiap individu untuk mencapai perubahan personalnya. Salah satu contoh dari kelompok terapi adalah kelompok konsultasi perkawinan, kelompok penderita narkotika, dan kelompok perokok berat. ${ }^{14}$

Selain komunikasi interpersonal dan kelompok, terdapat komunikasi massa sebagai substansi dari bentuk komunikasi sosial. Komunikasi massa adalah proses penyampaian pesan kepada khalayak sasaran ${ }^{15}$.Komunikasi massa melibatkan jumlah komunikan yang banyak, tersebar dalam area geografis yang luas, tetapi mempunyai perhatian dan minat terhadap isu yang sama. Pada komunikasi massa, umpan balik relatif bersifat tunda. Secara sadar atau tidak, di dalam komunikasi massa terjadi pula komunikasi interpersonal dan kelompok. ${ }^{16}$ Menurut Mc Quail yang dikutip oleh Bungin, komunikasi massa berproses dalam bentuk sebagai berikut:pertama, melakukan distribusi dan penerimaan informasi kepada masyarakat dalam skala besar. Kedua, proses komunikasi massa dilakukan satu arah, yaitu komunikator ke komunikan. Apabila terjadi interaksi diantara mereka, maka proses komunikasi akan terbalik menjadi komunikan ke komunikator. Namun, pesan yang disampaikan sifatnya terbatas, sehingga tetap saja didominasi oleh komunikator. Ketiga, proses komunikasi berlangsung asimetris antara komunikator dan komunikan. Hal itu menyebabkan komunikasi diantara mereka berlangsung datar dan bersifat sementara. Keempat, proses komunikasi massa berlangsung impersonal dan tanpa nama. Proses tersebut menjamin bahwa komunikasi massa akan sulit diidentifikasi bagi penggerak massa di jalan. Kelima, proses komunikasi massa berlangsung sesuai dengan hubungan kebutuhan di masyarakat. ${ }^{17}$

\section{Konsepsi Komunikasi Agama}

\footnotetext{
${ }^{14}$ Ibid.

${ }^{15}$ Wawan Kuswandi, Komunikasi Massa: Sebuah Analisis Isi Media Televisi (Jakarta: Rineka Cipta, 1996).

${ }^{16}$ Dani Vardiansyah, Pengantar Ilmu Komunikasi: Pendekatan Taksonomi Konseptual (Bogor: Ghalia Indonesia, 2004).

${ }^{17}$ Bungin, Sosiologi Komunikasi: Teori, Paradigma, Dan Diskursus Teknologi Komunikasi Di Masyarakat.
}

Dirasah, Vol. 3, No.2, Agustus 2020 
Istilah komunikasi agama terdiri dari dua suku kata, yaitu komunikasi dan agama. Kedua kata ini memiliki pengertian yang berbeda. Komunikasi menurut paradigma Lasswell, adalah proses penyampaian pesan oleh komunikator kepada komunikan melalui media yang menimbulkan efek tertentu. ${ }^{18}$

Sedangkan agama adalah sebagai seperangkat aturan yang mengatur hubungan manusia dengan dunia gaib, khususnya dengan Tuhannya, mengatur hubungan manusia dengan manusia lainnya, dan mengatur hubungan manusia dengan lingkungannya. Secara khusus, agama di definisikan sebagai suatu sistem keyakinan yang dianut dan tindakan-tindakan yang diwujudkan oleh suatu kelompok atau masyarakat dalam menginterpretasikan dan memberi tanggapan terhadap apa yang dirasakan dan diyakini sebagai sesuatu yang gaib dan suci. Para antropolog melihat hubungan manusia dengan Zat yang adikodrati itu dari sudut pandang kebudayaan. Hasil temuan mereka menunjukkan bahwa pada masyarakat yang masih memiliki kebudayaan asli (primitif) dijumpai adanya pola kebudayaan yang mencerminkan bentuk hubungan masyarakat dengan sesuatu yang mereka anggap adikuasa dan suci.

Menurut Devito, bentuk-bentuk komunikasi antar budaya meliputi bentuk-bentuk komunikasi yang lain, yaitu: komunikasi antar kelompok agama yang berbeda. Misalnya, antara orang Katolik Roma dengan Episkop, atau antara orang Islam dan orang Yahudi. ${ }^{19}$

Sedangkan Deddy Mulyana, yang dikutip oleh Liliweri, berpendapat bahwa komunikasi antar budaya adalah proses pertukaran pikiran dan makna antara orang-orang yang berbeda budaya. Sama halnya dengan komunikasi agama, yaitu proses komunikasi yang terjadi antara orang-orang yang seagama maupun orang-orang yang berbeda agama. ${ }^{20}$

Sementara itu, Liliweri sendiri berpendapat bahwa agama merupakan sistem keyakinan yang dianut dan tindakan-tindakan yang diwujudkan oleh suatu kelompok atau masyarakat yang menginterpretasi dan memberi respons terhadap apa yang dirasakan dan diyakini sebagai sesuatu yang bersifat gaib dan suci.Berdasarkan pengertian itu, agama sebagai suatu keyakinan yang dianut oleh suatu kelompok atau masyarakat menjadi norma dan nilai yang diyakini,

\footnotetext{
${ }^{18}$ Onong Uchjana Effendy, Ilmu Komunikasi: Teori Dan Praktek (Bandung: Remaja Rosda Karya, 1997).

${ }^{19}$ Joseph A. Devito, Komunikasi Antarmanusia (Jakarta: Professional Books, 1997).

${ }^{20}$ Alo Liliweri, Gatra-Gatra Komunikasi Antar Budaya (Yogyakarta: pustaka Pelajar, 2001).
} 
dipercayai, diimani sebagai suatu referensi, karena norma dan nilai itu mempunyai fungsi-fungsi tertentu. Fungsi-fungsi tersebut yang dirumuskan dalam tugas dan fungsi agama. Berhubung para penganut agama itu berada dalam suatu masyarakat, maka para sosiolog memandang bahwa semua agama dan lembaga keagamaan sebagai sebuah kelompok sosial. Sebagai sebuah kelompok sosial, agama dan lembaga keagamaan berfungsi sebagai lembaga pendidikan, pengawasan, pemupukan rasa persaudaraan, profetis atau kenabian, dan lain sebagainya. ${ }^{21}$

Namun, pada umumnya dapat dirumuskan dua fungsi utama agama, yaitu fungsi manifest dan latent.Fungsi manifest agama mencakup tiga aspek, yaitu: 1) menanamkan pola keyakinan yang disebut doktrin, yang menentukan sifat hubungan antar manusia, dan manusia dengan Tuhan; 2) ritual yang melambangkan doktrin dan mengingatkan manusia pada doktrin tersebut, dan 3) seperangkat norma perilaku yang konsisten dengan doktrin tersebut.Sedangkan fungsi latent adalah fungsi-fungsi yang tersembunyi dan bersifat tertutup. Fungsi ini dapat menciptakan konflik hubungan antar pribadi, baik dengan sesama anggota kelompok agama maupun dengan kelompok lain. Fungsi latent mempunyai kekuatan untuk menciptakan perasaan etnosentrisme dan superioritas yang pada gilirannya melahirkan fanatisme. Fungsi ini pun tetap diajarkan kepada anggota agama dan kelompok keagamaan untuk membantu mereka dalam mempertahankan dan menunjukkan ciri agamanya, bahkan untuk menetapkan status sosial mereka. ${ }^{22}$

Setiap masyarakat, apalagi yang majemuk, selalu terbentuk kelompokkelompok. Kelompok itu terbentuk karena para anggotanya mempunyai citacita yang didasarkan pada nilai atau norma yang sama-sama mereka terima dan patuhi. Sama halnya dengan agama. Manusia yang berkelompok berdasarkan keyakinan, kepercayaan, iman terhadap sesuatu yang bersifat sakral disebut kelompok agama. Karena itu, agama dapat dipandang sebagai suatu kelompok etnik. Keberadaan kelompok agama dapat dilihat dari simbol dan tanda, materi, pesan-pesan verbal dan nonverbal, petunjuk berupa materi dan immateri, bahkan sikap dan cara berpikir yang sifatnya abstrak. Para pengikut suatu agama kerapkali (bahkan dalam seluruh kehidupannya) menjadikan petunjukpetunjuk tersebut sebagai wahana, pesan serta pola yang mengatur interaksi,

\footnotetext{
${ }^{21}$ Ibid.

${ }^{22}$ Ibid.
}

Dirasah, Vol. 3, No.2, Agustus 2020 
relasi dan komunikasi, baik dalam ritual keagamaan hingga ke komunikasi yang bersifat intra kelompok maupun antar kelompok agama. ${ }^{23}$

Sebagaimana terdapat dalam al-Qur'an dan hadits Nabi, bahwa sesungguhnya Islam sangat menghormati keberagaman umat manusia dan tidak pernah memaksa siapa pun serta etnis mana pun untuk beragama sama. Keberagaman umat manusia merupakan hukum Allah (sunnatullah) dan tidak seorang pun bisa mengingkari dan menolaknya. Justru Nabi Muhammad bukan saja mengajarkan kepada umatnya untuk mengakui dan menghormati keberagaman umat manusia, tetapi sekaligus memberi contoh nyata dalam mempersatukan mereka. Nabi menjodohkan (menikahkan) seorang pembantu dekatnya yang berstatus budak dengan seorang gadis yang berasal dari Bani Bayadah yang telah merdeka. Nabi juga mengangkat Bilal (semula juga berstatus budak sebelum dimerdekakan oleh Abu Bakar) yang berkulit hitam untuk menjadi muadzin(penyeru umat Islam untuk menunaikan shalat). Nabi pun sering bekerja sama dan bergaul dengan orang-orang yang berlainan etnis, kelas sosial, status ekonomi, bahkan juga berlainan agama. Dalam suatu kesempatan berbincang-bincang dengan para sahabat, Nabi pernah tiba-tiba berdiri menghormati rombongan pembawa jenazah yang tengah lewat. Melihat hal itu, sebagian sahabat yang telah mengetahui jenazah siapa yang tengah lewat itu bertanya kepada Nabi, "bukankah jenazah yang lewat itu seorang Yahudi, ya Rasul ?". Apa jawab Nabi Muhammad ?. "Bukankah dia juga jiwa (manusia)." Islam memang tidak membedakan umat manusia dengan dasar perbedaan etnis, kebangsaan, warna kulit, bahasa, adat istiadat, ataupun agama. Semua umat manusia dipandangnya memiliki hak yang sama. Semua diciptakan oleh Allah SWT dalam status yang sama pula, yaitu sebaik-baik penciptaan (ahsanutaqwim) dan sebagai wakil Tuhan di bumi (khalifah filardl). Selain itu, sebagaimana firman Allah SWT dalam surah al-Hujurat ayat 13, bahwa pada hakikatnya semua umat manusia berasal dari seorang laki-laki dan seorang perempuan, yaitu Adam dan Hawa. Jadi, sangat jelas bahwa pada hakikatnya semua umat manusia berasal dari ayah dan ibu yang sama. ${ }^{24}$

\section{Hasil Penelitian dan Pembahasan}

\footnotetext{
${ }^{23}$ Ibid.

${ }^{24}$ Sudarto, Konflik Islam-Kristen: Menguak Akar Masalah Hubungan Antar Umat Beragama Di Indonesia (Semarang: Pustaka Rizki Putra, 1999).
} 
Keberadaan penyuluh agama Islam fungsional pada Kementerian Agama Kabupaten Bangkalan memiliki peran yang sangat signifikan dalam upaya melakukan pembinaan terhadap para narapidana yang ada di rumah tahanan (rutan) kelas II-B Kabupaten Bangkalan. Peran tersebut termanifestasikan dalam bentuk melakukan penyuluhan secara rutin di rutan kelas II-B Kabupaten Bangkalan, yaitu setiap hari Jum'at selama dua kali dalam satu bulan,tepatnya pada minggu pertama dan minggu ketiga.

Teknis penyuluhan agama di rutan kelas II-B Kabupaten Bangkalan dalam upaya melakukan pembinaan terhadap para narapidana, dibagi menjadi dua kelompok dan ditempatkan pada ruangan yang berbeda. Dua kelompok tersebut adalah narapidana laki-laki dan narapidana perempuan. Untuk narapidana laki-laki, kegiatan penyuluhan agama dilakukan oleh para penyuluh agama Islam fungsional yang berjenis kelamin laki-laki. Sedangkan narapidana perempuan, kegiatan penyuluhan agama dilakukan oleh para penyuluh agama Islam fungsional yang berjenis kelamin perempuan. Hal itu dilakukan untuk menjaga kondusifitas kegiatan penyuluhan agama dalam upaya melakukan pembinaan terhadap para narapidana yang ada di rutan kelas II-B Kabupaten Bangkalan.

Kegiatan pembinaan yang berbentuk pemberian penyuluhan yang dilakukan oleh para penyuluh agama Islam fungsional terhadap para narapidana yang ada di rutan kelas II-B Kabupaten Bangkalan dilakukan dengan menggunakan pendekatan agama. Dengan pendekatan tersebut, diharapkan para narapidana yang ada di rutan kelas II-B Kabupaten Bangkalan bisa menjadi pribadi yang baik sesuai dengan tuntunan agama selama menjalani masa hukumannya, terlebih lagi ketika mereka kelak sudah keluar dari rutan.

Kegiatan pembinaan yang berbentuk pemberian penyuluhan dengan menggunakan pendekatan agama yang dilakukan oleh penyuluh agama Islam fungsional tersebut, antara lain:pertama, mengajak para narapidana untuk membaca surat Yasin, tahlil, istighasah, dan shalawat. Ajakan untuk membaca surat Yasin, tahlil, dan istighasah dilakukan oleh para penyuluh agama Islam fungsional dengan tujuan agar kegiatan penyuluhan agama di rutan kelas II-B Kabupaten Bangkalan dapat berjalan dengan baik dan mampu memberikan nilai spiritual yang mendalam bagi para narapidana. Sedangkan ajakan untuk membaca shalawat dilakukan oleh para penyuluh agama Islam fungsional pada 
setiap momen-momen tertentu, seperti pada bulan maulud. Hal itu dilakukan agar mendapatkan syafaat dari Nabi Muhammad SAW kelak di hari kiamat.

Kedua, memberikan ceramah agama. Pemberian ceramah agama dilakukan oleh penyuluh agama Islam fungsional dengan tujuan untuk pembinaan mental, moral, dan ketaqwaan kepada Tuhan Yang Maha Esa. Pemberian ceramah agama dilakukan setiap hari Jum'at dua kali dalam satu bulan. Ceramah agama pun dimulai pada jam 09.00 pagi,karena para narapidana yang berjenis kelamin laki-laki harus menunaikanibadah shalatJum'at.Pemberian ceramah agama pertama kali dilakukan sekitar akhir tahun 2015 sampai pertengahan tahun 2016, yang pada waktuitu masih menggunakan metode ceramah tanpa membuka peluang untuk sesi tanya jawab.Namun karena ada permintaan dari para narapidana, khususnya narapidana perempuan, maka sesi tanya jawab pun diberikan setelah materi ceramah agama selesai disampaikan. Materi ceramah yang disampaikan kepada para narapidana adalah tentang: thaharah, wudhu, dan shalat. Karena pada kenyataannya para narapidana masih banyak yang belum memahami tentang seluk beluk thaharah, wudhu, dan shalat yang sesuai dengan tuntunan agama.

Ketiga, menggunakan pendekatan bimbingan dan konseling dalam upaya menyelesaikan permasalahan yang dialami oleh para narapidana. Pendekatan bimbingan dan konseling digunakan oleh penyuluh agama Islam fungsional dengan tujuan untuk membantu menyelesaikan permasalahan yang dialami oleh para narapidana yang ingin agar permasalahan hidupnya mendapatkan solusi. Pendekatan bimbingan dan konseling ini pertama kali diterapkan pada tahun 2017,karena adanya permohonan dari salah satu narapidana perempuan yang ingin agar permasalahan hidupnya mendapatkan solusi. Narapidana perempuan tersebut bernama Eka Kartika Sari yang menjalani masa hukuman di rutan kelas II-B Kabupaten Bangkalan karena terlibat kasus pembunuhan berencana. Dengan menggunakan pendekatan bimbingan dan konseling, kepekaan dan kesabaran para penyuluh agama Islam fungsional pun dibutuhkan dalam upaya mendengarkan permasalahan yang dihadapi oleh narapidana perempuan tersebut. Sehingga, dengan pendekatan bimbingan dan konseling tersebut, sang narapidana perempuan tersebut pun akhirnya dapat menjalani kembali kehidupan yang lebih baik. Indikasi perubahan perilaku dari narapidana perempuan tersebut yaitu ia mulai menunaikan kembali ibadah shalat yang selama ini telah lama tidak dilakukannya, meskipun shalatnya pun masih belum 
mampu ditunaikan sebanyak lima waktu. Disamping itu, kata penyesalan pun telah terlontar dari sang narapidana perempuan tersebut karena telah terlibat dalam pembunuhan berencana.

Peran penyuluh agama Islam fungsional tersebut diatas dalam upaya melakukan pembinaan terhadap narapidana yang ada di rutan kelas II-B Kabupaten Bangkalan, dalam perspektif komunikasi sosial merupakan sebuah bentuk komunikasi sosial yang meliputi: komunikasi interpersonal (komunikasi antar pribadi) dan komunikasi kelompok. Dimana komunikasi interpersonal dan kelompok tersebut merupakan sebuah proses komunikasi yang berlangsung antara dua orang atau lebih secara tatap muka. ${ }^{25}$ Disamping itu, komunikasi interpersonal mempunyai peranan dalam membentuk hubungan perasaan, pemahaman informasi, dukungan, citra diri, dan pemahaman atas harapan orang lain. Untuk mengembangkan hubungan, terdapat empat poin penting dalam proses komunikasi interpersonal. Pertama, pengungkapan diri (self disclosure). Pengungkapan diri adalah proses pengungkapan informasi diri seseorang kepada orang lain. Kedua, penetrasi sosial. Penetrasi sosial adalah proses yang dialami seseorang untuk saling mengenal dengan orang lain, sehingga secara bertahap akan mempermudah dalam membahas topik pembicaraan yang lebih pribadi. Ketiga, proses pandangan (process of view). Teori ini menganggap bahwa kualitas dan sifat hubungan dapat diperkirakan hanya dengan menggunakan dan mengkombinasikan atribut masing-masing sebagai individu, seperti senyuman. Keempat, pertukaran sosial (social exchange). Pertukaran sosial menelaah tentang kontribusi seseorang dalam suatu hubungan untuk mempengaruhi orang lain. ${ }^{26}$

Sedangkan peran penyuluh agama Islam fungsional tersebut diatas dalam upaya melakukan pembinaan terhadap narapidana yang ada di rutan kelas II-B Kabupaten Bangkalan, dalam perspektif komunikasi agama merupakan sebuah usaha untuk mengarahkan para narapidana agar menyadari kesalahan yang telah dilakukannya selama ini, sehingga ia harus menjalani masa hukuman di rutan. Disamping itu, pendekatan komunikasi agama yang digunakan oleh penyuluh agama Islam fungsional tersebut diatas juga bertujuan untuk mengarahkan para narapidana agar kembali kepada kehidupan yang sesuai dengan tuntunan

\footnotetext{
${ }^{25}$ Cangara, Pengantar Ilmu Komunikasi.

${ }^{26}$ Bungin, Sosiologi Komunikasi: Teori, Paradigma, Dan Diskursus Teknologi Komunikasi Di Masyarakat.
}

Dirasah, Vol. 3, No.2, Agustus 2020 
agama. Apa yang dilakukan oleh penyuluh agama Islam fungsional tersebut diatas selaras dengan firman Allah SWT dalam surat an-Nahl ayat 125:

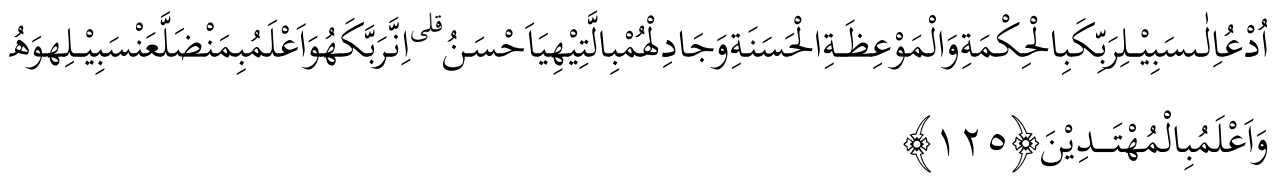

Artinya: Serulah (manusia) kepada jalan Tuhanmu dengan hikmah dan pelajaran yang baik dan bantahlah mereka dengan cara yang baik. Sesungguhnya Tuhanmu, Dialah yang lebih mengetahui tentang siapa yang tersesat dari jalan-Nya dan Dia-lah yang lebih mengetahui orang-orang yang mendapat petunjuk. (Q.s. An-Nahl: 125) ${ }^{27}$

Dalam menjalankan tugasnya, yaitu memberikan penyuluhan dalam upaya melakukan pembinaan terhadap para narapidana yang ada di rutan kelas II-B Kabupaten Bangkalan, para penyuluh agama Islam fungsional Kantor Kementerian Agama Kabupaten Bangkalan mengalami berbagai kendala. Kendala-kendala tersebut antara lain: 1) Kendala internal, berupa: a) perbedaan budaya. Narapidanayang ada di rutan kelas II-B Kabupaten Bangkalan berasal dari berbagai wilayah di JawaTimur. Namun jumlah narapidana yang berasal dari Madura merupakan penghuni mayoritas. Hal itu menjadi kendala tersendiri bagi penyuluh agama Islam fungsional dalam upaya melakukan pembinaan, mengingat narapidana yang dihadapi mempunyai karakteristik budaya yang beragam. Sehingga membutuhkan pendekatan dan metode yang berbeda. b) Latar belakang pendidikan. Dengan latar belakang pendidikan para narapidana yang ada di rutan kelas II-B Kabupaten Bangkalan yang mayoritas rendah, sangat berpengaruh pula terhadap kemampuan mereka dalam memahami dan menangkap bahasa-bahasa ilmiah atau makna kalimat yang sifatnya tidak langsung. Sehingga dalam proses penyuluhan dalam upaya melakukan pembinaan terhadap para narapidana yang ada di rutan kelas II-B Kabupaten Bangkalan, para penyuluh agama Islam fungsional dituntut untuk bisa belajar dalam memahami dan berkomunikasi dengan menggunakan bahasa yang lebih jelas dan dapat dimengerti oleh para narapidana. c) Bentuk kasus. Para narapidana yang ada di rutan kelas II-B Kabupaten Bangkalan memiliki latar

\footnotetext{
${ }^{27}$ Da'wah dan Irsyad Kerajaan Saudi Arabia Kementerian Urusan Agama Islam, Wakaf, AlQur'an Dan Terjemahnya (Madina: Al-Malik Fahd Li Thiba'at Al-Mushaf Asy-Syarif, 1990).
} 
belakang kasus yang berbeda-beda. Mulai dari kasus narkoba, penipuan, perampokan, pemerkosaan, hingga pembunuhan. Hal itu menjadi kendala tersendiri bagi penyuluh agama Islam fungsional dalam upaya menentukan materi dan metode penyuluhan yang dianggap sangat tepat. 2) Kendala eksternal, yaitu berupa infra struktur rutan kelas II-B Kabupaten Bangkalan yang kurang mamadai. Kondisi gedung bangunan rutan yang sudah lama mempengaruhi fasilitas kamar mandi rutan yang sangat terbatas. Jumlah kamar mandi rutan tidak bisa menampung seluruh narapidana yang ada di dalamnya. Sehingga mempengaruhi pula proses penyuluhan. Para penyuluh agama Islam fungsional seringkali, bahkan hampir tiap kali melakukan penyuluhan, harus menunggu paranarapidana selesai mandi.

\section{Penutup}

Berdasarkan hasil temuan penelitian ini, ada beberapa poin penting yang dapat disimpulkan terkait dengan peran penyuluh agama Islam fungsional dalam upaya melakukan pembinaan terhadap narapidana di rutan kelas II-B Kabupaten Bangkalan. Pertama, peran penyuluh agama Islam fungsional dalam upaya melakukan pembinaan terhadap narapidana di rutan kelas II-B Kabupaten Bangkalan dengan menggunakan pendekatan komunikasi sosial dan agama termanifestasikan dalam bentuk melakukan penyuluhan secara rutin di rutan kelas II-B Kabupaten Bangkalan, yaitu setiap hari Jum'at selama dua kali dalam satu bulan, tepatnya pada minggu pertama dan minggu ketiga. Kegiatan pembinaan yang berbentuk pemberian penyuluhan yang dilakukan oleh penyuluh agama Islam fungsional tersebut, antara lain:mengajak para narapidana untuk membaca surat Yasin, tahlil, istighasah, dan shalawat; memberikan ceramah agama; serta menggunakan pendekatan bimbingan dan konseling dalam upaya menyelesaikan permasalahan yang dialami oleh para narapidana.

Kedua, kendala-kendala yang dihadapi oleh penyuluh agama Islam fungsional dalam upaya melakukan pembinaan terhadap narapidana di rutan kelas II-B Kabupaten Bangkalan dengan menggunakan pendekatan komunikasi sosial dan agama yaitu adanya kendala internal dan eksternal. Kendala internal berupa: adanya perbedaan latar belakang budaya dari para narapidana, adanya perbedaan latar belakang pendidikan dari para narapidana, dan adanya perbedaan kasus yang melatar belakangi para narapidana harus menjalani masa 
hukuman di rutan. Sedangkan kendala eksternal berupa kurang memadainya infra struktur kamar mandi yang ada di rutan kelas II-B Kabupaten Bangkalan.

\section{Daftar Pustaka}

Badan Litbang dan Diklat Kemenag RI. "Naskah Akademik Bagi Penyuluh Agama." Jakarta, 2015.

Bulaeng, Andi. Metode Penelitian Komunikasi Kontemporer. Yogyakarta: Andi Offset, 2004.

Bungin, Burhan. Analisis Data Penelitian Kualitatif. Jakarta: Raja Grafindo Persada, 2004.

—. Sosiologi Komunikasi: Teori, Paradigma, Dan Diskursus Teknologi Komunikasi Di Masyarakat. Jakarta: Kencana, 2007.

Cangara, Hafied. Pengantar Ilmu Komunikasi. Jakarta: Raja Grafindo Persada, 1998.

Daymon, Christine, and Immy Holloway. Metode-Metode Riset Kualitatif Dalam Public Relations \& Marketing Communications. Edited by Terj. Cahya Wiratama. Yogyakarta: Bentang, 2008.

Devito, Joseph A. Komunikasi Antarmanusia. Jakarta: Professional Books, 1997.

Effendy, Onong Uchjana. Ilmu Komunikasi: Teori Dan Praktek. Bandung: Remaja Rosda Karya, 1997.

Kementerian Urusan Agama Islam, Wakaf, Da'wah dan Irsyad Kerajaan Saudi Arabia. Al-Qur'an Dan Terjemahnya. Madina: Al-Malik Fahd Li Thiba'at Al-Mushaf Asy-Syarif, 1990.

Kuswandi, Wawan. Komunikasi Massa: Sebuah Analisis Isi Media Televisi. Jakarta: Rineka Cipta, 1996.

Liliweri, Alo. Gatra-Gatra Komunikasi Antar Budaya. Yogyakarta: pustaka Pelajar, 2001. 
"Majalah Bimas Islam Kementerian Agama RI Edisi 4." Ditjen Bimas Islam Kemenag RI, 2016.

Mantra, Ida Bagoes. Filsafat Penelitian Dan Metode Penelitian Sosial. Yogyakarta: pustaka Pelajar, 2004.

Mukhlisuddin. "Peran Penyuluh Agama Islam Dalam Mereduksi Konflik Dan Mengintegrasikan Masyarakat (Studi Kasus Konflik Pelaksanaan Shalat Tarawih Di Kecamatan Bandar Dua, Kabupaten Pidie Jaya).” Jurnal Bimas Islam 9, no. 1 (2016).

Rakhmat, Jalaluddin. Psikologi Komunikasi. Bandung: Remaja Rosda Karya, 2007.

RI, Ditjen Bimas Islam Kemenag. Himpunan Peraturan Tentang Jabatan Fungsional Penyuluh Agama Dan Angka Kreditnya. Jakarta: Ditjen Bimas Islam Kemenag RI, 2011.

Sudarto. Konflik Islam-Kristen: Menguak Akar Masalah Hubungan Antar Umat Beragama Di Indonesia. Semarang: Pustaka Rizki Putra, 1999.

Vardiansyah, Dani. Pengantar Ilmu Komunikasi: Pendekatan Taksonomi Konseptual. Bogor: Ghalia Indonesia, 2004.

Copyright (C) 2020Journal Dirasah: Vol. 3, No.2,Agustus 2020, p-ISSN: 2615-0212, e-ISSN; 2621-2838

Copyright rests with the authors

Copyright of Jurnal Dirasah is the property of Jurnal Dirasah and its content may not be copied oremailed to multiple sites or posted to a listserv without the copyright holder's express writtenpermission. However, users may print, download, or email articles for individual use. https://ejournal.iaifa.ac.id/index.php/dirasah 